\title{
Effects of Different Tastants on Parotid Saliva Flow and Composition
}

\author{
E. Neyraud • C. I. Heinzerling • J. H. F. Bult • \\ C. Mesmin • E. Dransfield
}

Received: 12 December 2008 / Accepted: 24 February 2009/Published online: 13 March 2009

(C) The Author(s) 2009. This article is published with open access at Springerlink.com

\begin{abstract}
Saliva from parotid glands plays a role in taste perception. Parotid saliva is also stimulated by tastants. The aim of this work is to investigate the effects of different tastants on the parotid salivary response in six subjects. Five tastants were given in different concentrations in solution and held in the mouth for $10 \mathrm{~s}$. The flow rate, protein concentration, and $\mathrm{pH}$ of secreted parotid saliva were monitored continuously for $5 \mathrm{~min}$. Stimulation by tastants on flow rate response consists of an immediate rise in flow followed by a plateau and a rapid return to prestimulus flow. Response of $\mathrm{pH}$ results in a slower increase while protein concentration consists in a slower decrease, both followed by a return to prestimulus levels in
\end{abstract}

E. Neyraud · C. I. Heinzerling · J. H. F. Bult · C. Mesmin •

E. Dransfield

TI Food and Nutrition (former WCFS),

P.O. Box 557, 6700 AN Wageningen, The Netherlands

E. Neyraud

Wageningen UR, Agrotechnology and Food Innovations,

Bornsesteeg 59,

6700 AA Wageningen, The Netherlands

E. Neyraud

TNO,

Utrechtseweg 48, P.O. Box 360, 3700 AJ Zeist, The Netherlands

C. I. Heinzerling

Laboratory of Food Chemistry, Wageningen University,

P.O. Box 8129, 6700 EV Wageningen, The Netherlands

J. H. F. Bult

NIZO Food Research B.V.,

P.O. Box 20, 6710 BA Ede, The Netherlands

E. Neyraud $(\square)$

UMR1129 FLAVIC, ENESAD, INRA, Université de Bourgogne,

17 rue Sully, BP 86510, 21065 Dijon Cedex, France

e-mail: eric.neyraud@dijon.inra.fr about $4 \mathrm{~min}$. From a resting flow rate of about $140 \mu \mathrm{L} / \mathrm{min}$, an increase in flow rate to $370 \mu \mathrm{L} / \mathrm{min}$ was caused by stimulation for $10 \mathrm{~s}$ with $10 \mathrm{~mL}$ of solutions of $0.01 \mathrm{M}$ citric acid, $0.13 \mathrm{M} \mathrm{MgSO}_{4}, 0.25 \mathrm{M}$ monosodium glutamate, $0.5 \mathrm{M} \mathrm{NaCl}$, or $0.5 \mathrm{M}$ sucrose. Comparisons of the different tastants showed that the $\mathrm{pH}$ of stimulated parotid saliva increased linearly $(r=0.9)$, irrespective of the nature of the tastant. Protein concentration decreased $(r=-0.45)$ and protein amount increases $(r=0.58)$ with increase in flow rate for all tastants. Corrected for the effects of flow rate, protein amount depended on the nature of the tastant with the greatest secretion after stimulation by citric acid. Flow rate was largely responsible for $\mathrm{pH}$ but tastant appears to play an additional role with flow rate on protein secretion.

Keywords Taste $\cdot$ Saliva $\cdot$ Parotid $\cdot$ Protein $\cdot \mathrm{pH} \cdot$ Flow

\section{Introduction}

Saliva plays an important role in teeth maintenance by its antimicrobial action and also in digestion and food perception (Mese and Matsuo 2007). During these two last actions, saliva is predominantly released from the parotid glands. During eating, the proportion of parotid saliva in whole saliva can increase from $0 \%$ to more than $50 \%$ (Humphrey and Williamson 2001). Such an increase, due to stimulation by mastication and/or taste compounds, has been called the parotid salivary reflex (Chauncey and Shannon 1960). Consequently, parotid saliva participates largely in bolus formation and digestion, e.g., by the contribution of $\alpha$-amylase in starch hydrolysis. In addition, parotid saliva contributes to taste perception. The large amount of bicarbonate ions in parotid saliva have a buffering action on acids, thus modifying sourness percep- 
tion (Christensen et al. 1987; Lugaz et al. 2005). Moreover, bicarbonate concentration increases with flow rate and since flow rate tends to increase with acidity, the parotid saliva reflex promotes the protection of the oral medium against acidification. This implies that salivary response is adaptive, since the nature of the response is modulated by the "harmful" nature of the stimulus. This is supported by earlier finding showing that whole saliva proteome can be modified by the nature of the tastant with an overexpression of proteins involved in inflammatory response after stimulation by sour, bitter, and umami tastants but not after sweet (Neyraud et al. 2006). Others reported a possible specific response of parotid saliva to tastant by a different protein pattern expression (Dawes 1984) or an increase of $\alpha$-amylase concentration after drinking sugar solution but not after sham drinking, suggesting a metabolic adaptation of the parotid glands and their specific participation in the digestion and regulation of appetite (Harthoorn et al. 2008).

Studying parotid saliva characteristics in response to a stimulus is complex. It was shown that characteristics like protein concentration or $\mathrm{pH}$ are linked to flow rate especially when stimulated by mastication (Neyraud et al. 2009 in press). When collected with a Lashley cup after stimulation and analyzed in vitro, parotid saliva does not resemble saliva at the exit of the parotid duct. This is due to the delay existing to reach the exit of the collecting tube from the exit of the parotid duct. The delay depends of the volume of the tubing and the flow rate. Batch sampling is also not recommended for chemical reasons, for example, the diminution of the buffer capacity due to $\mathrm{CO}_{2}$ production from bicarbonate ions at the contact of the air. In addition, this batch-wise analysis of saliva does not allow characterization with high time resolution, which is desirable for the study of adaptive response to stimuli. We have developed a system able to collect parotid saliva from the exit of the parotid duct with a Lashley cup that continuously measures flow rate, $\mathrm{pH}$, and protein concentration by absorbance $\left(A_{280}\right)$. This system synchronizes these continuous measures in time as if they were measured at the exit of the duct (Neyraud et al. 2009).

The aim of this work is to study continuous time-release profiles of parotid saliva characteristics in response to different tastant stimulations in order to establish relationships between $\mathrm{pH}$ and protein concentration as a function of flow rate.

\section{Material and Methods}

\section{Subjects and Protocol}

Three male and three female subjects, aged 22 to 39 years, nonsmokers and of good general health participated in three morning sessions of $2 \mathrm{~h}$ each. While subjects were sitting upright, a Lashley cup was fitted over the exit of the duct of the right parotid gland. Then, subjects chewed a piece of parafilm until the collection system $(820 \mu \mathrm{L})$ was filled with saliva. Each session started with a rest of $5 \mathrm{~min}$. Then, a $15-\mathrm{mL}$ medicine cup of distilled water was presented to the subject who was instructed to sip the solution during $10 \mathrm{~s}$ in a uniform fashion, to spit it out, and to have a rest of $5 \mathrm{~min}$ before the next solution. During the first session, increasing concentrations of citric acid in distilled water were presented $(0.25,0.5,1,2.5,5,10,30,75,150$, and $300 \mathrm{mM}$ ). Following the same protocol, the second session consisted of tasting sucrose solutions $(0.1,0.2,0.5,1.5$, and $2 \mathrm{M}$ ). After a break of at least 15 min during which the subject rinsed his mouth with water, $\mathrm{NaCl}$ solutions $(0.05$, $0.1,0.2,0.3$, and $0.5 \mathrm{M}$ ) were tasted. Finally, during a third session, solutions of monosodium glutamate (MSG; 0.12, $0.25,0.5,0.75$, and $1 \mathrm{M})$ and $\mathrm{MgSO}_{4}(0.25,0.5,0.75,1$, and $1.25 \mathrm{M}$ ) were presented. The first solution tasted at the beginning of each series was distilled water. In sucrose, $\mathrm{NaCl}, \mathrm{MSG}$, and $\mathrm{MgSO}_{4}$ sessions, the last stimulus used was always $10 \mathrm{~mL}$ of a $75-\mathrm{mM}$ citric acid solution. The collection system was then flushed by chewing a piece of parafilm for $5 \mathrm{~min}$ to acquire measures from the saliva that was still in the system after the last stimulation.

The protocol was carried out in accordance with the guidelines of Ethical Committee of Wageningen University. The subjects reported no discomfort during the testing. All subjects gave informed consent.

\section{Continuous Recording of Parotid Saliva}

The system, used to collect and measure parotid saliva characteristics, was described in detail elsewhere (Neyraud et al. 2009). Therefore, here, we just give a brief description.

Parotid saliva was collected from the orifice of the Stensen's duct using a Lashley cup connected by $0.4 \mathrm{~m}$ of Tygon tube (internal diameter of $0.5 \mathrm{~mm}$ ) to a flow meter (tubing volume between Lashley cup and flow meter $242 \mu \mathrm{L}$ ), an absorbance cell (tubing volume $261 \mu \mathrm{L}$ ), and a $\mathrm{pH}$ probe (tubing volume $430 \mu \mathrm{L}$ ). The flow was recorded with an ASL 1430-16 liquid mass flow meter (Sensirion, Stafa, Switzerland). Absorbance $\left(A_{280}\right)$ was determined through a $1.5-\mathrm{mm}$ light path with an internal volume of $20 \mu \mathrm{L}$ using a deuterium light source DH-2000-BAL (Ocean Optics, The Netherlands). From stimulated and nonstimulated saliva, protein concentration (Bradford protein assay Quick Start ${ }^{\mathrm{TM}}$; Bio-Rad, The Netherlands) was linearly related $(R=0.87, p<0.01)$ to absorbance: protein concentration $(\mathrm{g} / \mathrm{L})=0.35\left(A_{280}\right)+0.49$. The $\mathrm{pH}$ was measured with a FTPH $2 \mathrm{~S}$ probe (Lazar Research Laboratories, California) coupled to an A to D converter (PT-104, Pico Technology, UK). 
Flow rate, $A_{280}$, and $\mathrm{pH}$ values were sampled synchronously at $3.125 \mathrm{~Hz}$ and were assigned to release times into the Lashley cup that were calculated from cumulative flows and the volumes between the Lashley cup and the absorbance cell and the $\mathrm{pH}$ probe, respectively. All sampling, calibration, and calculations were performed continuously by a Delphi-based (Borland Software Corp., Cupertino, CA, USA) computer program (Neyraud et al. 2009).

\section{Variables Selected}

Stimulations by tastants yielded similar time-response curves for flow rate, $\mathrm{pH}$, and $A_{280 \mathrm{~nm}}$ (Fig. 1). Three variables were defined to characterize these curves quantitatively in terms of flow rate response and event time: The peak of flow $\left(F_{\text {peak }}\right)$ consisting of the average of the five maximum values following the instantaneous increase of flow rate after stimulation and its corresponding time ( $T$ $\left.F_{\text {peak }}\right)$, the accumulated flow during the first minute after stimulation $\left(F_{60} \mathrm{~s}\right)$ corresponding to the volume secreted during the first minute after stimulation, and the total flow $\left(F_{\text {tot }}\right)$ corresponding to the volume of fluid secreted after stimulation until a return to a baseline level (before stimulation) and its corresponding time $\left(T-F_{\text {tot }}\right)$. Measured $\mathrm{pH}$ was expressed as the maximum $\mathrm{pH}$ value after stimulation $\left(\mathrm{pH}_{\max }\right)$. Two variables related to proteins were the protein concentration $\left(P_{\text {conc }}\right)$ corresponding to the average concentration of protein secreted during the $5 \mathrm{~min}$ after stimulation and the total protein amount $\left(P_{\text {tot }}\right)$ which corresponds to the instantaneous concentration in protein multiplied by the corresponding flow rate.

\section{Data Analysis}

Data analysis consisted of two stages:

(a) Since the main interest is in the effects of flow rates and tastants on saliva composition, the first stage consisted of testing whether the used method of manipulating stimulus concentration and tastant indeed affected flow rates significantly. Hence, effects on flow rate were tested by analysis of variance (ANOVA) for the variables tastant (fixed factor; five categories), concentration (fixed factor; ten categories for citric acid, five categories for sucrose, MSG, $\mathrm{MgSO}_{4}$, and $\mathrm{NaCl}$ ), and subjects (random factor; six categories). The test included all main effects and twoway interactions.

(b) Taking into account the expected effects of flow rate after stimulation on salivary $\mathrm{pH}$, average protein concentration during the first $5 \mathrm{~min}$ after stimulation ( $P_{\text {conc }}$, milligrams per milliliter), and total amount of
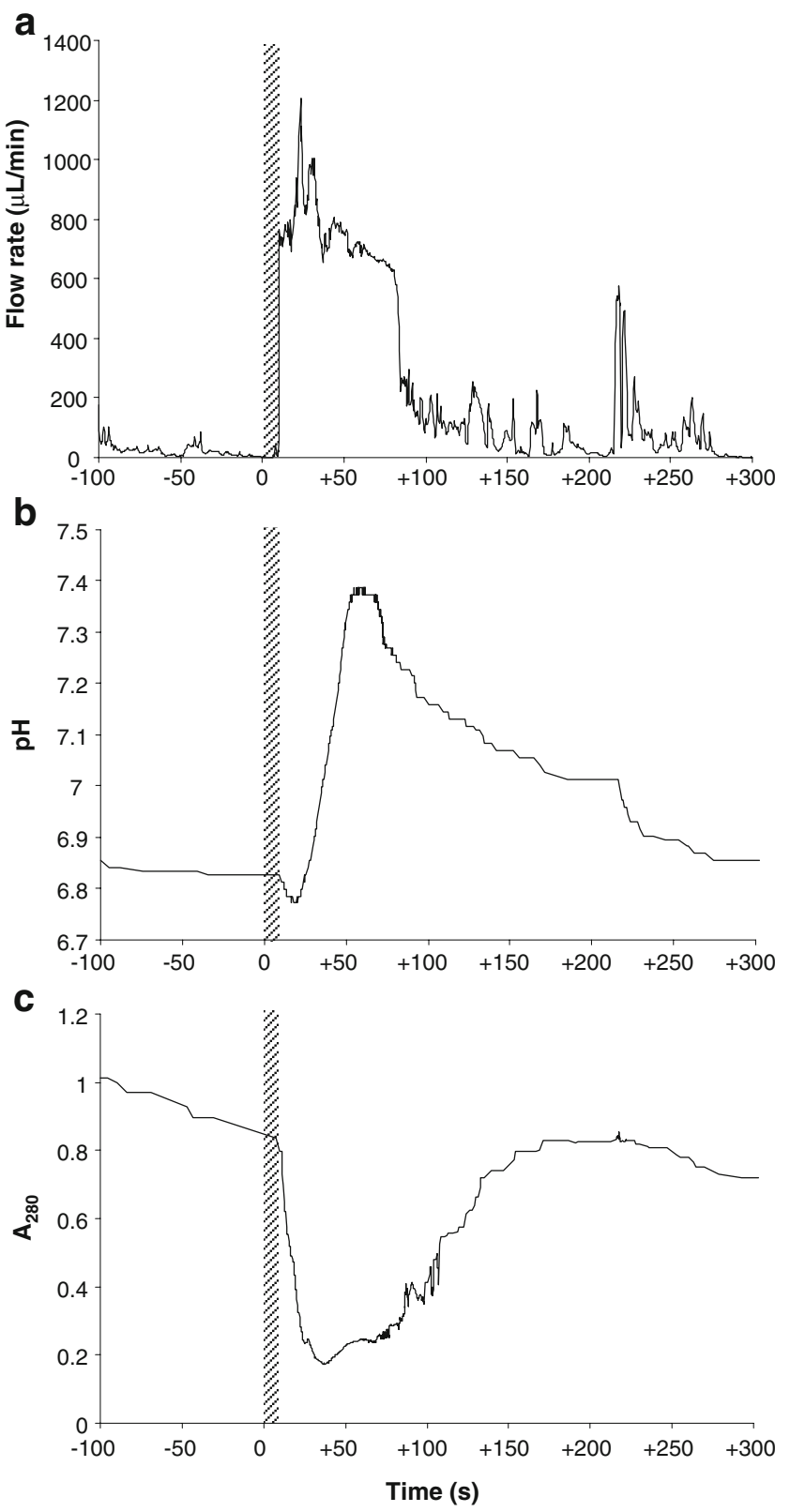

Fig. 1 Continuous parotid saliva flow (a), $\mathrm{pH}(\mathbf{b})$, and absorbance at $280 \mathrm{~nm}$ (c) of one subject in response to $10 \mathrm{~mL}$ of $30 \mathrm{mM}$ citric acid placed in the mouth for $10 \mathrm{~s}$ (at hatched line)

protein released during the first $5 \mathrm{~min}$ after stimulation ( $P_{\text {tot }}$, milligrams), the modulating effects of tastant on $\mathrm{pH}, P_{\text {conc }}$, and $P_{\text {tot }}$ were tested by ANOVA, including flow rate as a covariate, tastant as a fixed factor (five categories), and subjects as a random factor (six categories).

Duncan's multiple range statistic was used for post hoc analysis of tastant effects, performed on data from which trends due to flow rate were removed. This prevents spurious effects introduced by an inhomogeneous distribution of tastants over flow rates. 


\section{Results}

Analysis of the Continuous Response Curves

Continuous flow rate, $\mathrm{pH}$, and $A_{280}$ curves after stimulation with $30 \mathrm{mM}$ citric acid for one subject are presented in Fig. 1. Qualitative description of the response can be done as follows: The stimulus induced an instantaneous increase in flow rate from less than $10 \mu \mathrm{L} / \mathrm{min}$ to a maximum value (about $1,200 \mu \mathrm{L} / \mathrm{min}$ ) after about $30 \mathrm{~s}$. The flow rate remained at $600 \mu \mathrm{L} / \mathrm{min}$ for a further $50 \mathrm{~s}$ before decreasing abruptly and reaching the resting level after a further $100 \mathrm{~s}$ (Fig. 1a). A similar evolution was seen for $\mathrm{pH}$. The $\mathrm{pH}$ increased from a resting value of 6.85 to a maximum value of 7.4 at $60 \mathrm{~s}$ before decreasing slowly to the resting level (Fig. 1b). The $A_{280}$ pattern was the mirror image of $\mathrm{pH}$ with a decrease following the stimulus following by a slow increase (Fig. 1c).

A delay can be observed for reaching either the peak of $\mathrm{pH}$ or $A_{280}$. This can be explained by the diffusion of compounds within the system. For other subjects and tastants, the response curves were following the same trend.

\section{Tastant Effects on Flow Rate}

$F_{\text {peak }}$ value is always higher than the corresponding $F_{60 \text { s }}$ or $F_{\text {tot }}$, except for citric acid concentrations over $10 \mathrm{mM}$. For all tastant, $F_{60} \mathrm{~s}$ was similar to $F_{\text {tot }}$ except for citric acid concentration over $10 \mathrm{mM}$ (Fig. 2). No significant effects of the tastant nature on the three flow measures were found on water and $75 \mathrm{mM}$ citric acid stimuli, used at the beginning and at the end of each protocol, respectively.

There was no systematic salivary response for citric acid below $2.5 \mathrm{mM}$. Between 2.5 and $30 \mathrm{mM}$, flow rates increased and from $30 \mathrm{mM}$ and onwards, flow measures remained at a plateau of $0.8 \mathrm{~mL} / \mathrm{min}$ for the peak and $0.6 \mathrm{~mL} / \mathrm{min}$, for $F_{60 \mathrm{~s}} . F_{\text {tot }}$ reached a plateau $(1.2 \mathrm{~mL} / \mathrm{min})$ above concentrations of $75 \mathrm{mM}$ (Fig. 2a).

For the other tastants tested, $F_{60 \mathrm{~s}}$ and $F_{\text {tot }}$ were always above the value obtained after stimulation with water and always below the values of the citric acid plateau suggesting that the used tastant solutions did not lead to a maximum response of the gland. The most consistent ordinal doseresponse patterns were found for sucrose (Fig. 2b) and MSG (Fig. 2d). For $\mathrm{NaCl}$ (Fig. 2c) and $\mathrm{MgSO}_{4}$ (Fig. 2e), doseresponse patterns were less consistently ordinal.

ANOVA of flow rate results revealed significant effects of tastant $[F(4,20)=5.37, p<0.01]$, concentration $[F(15$, $75)=14.06, p<0.001]$, and significant interactions for tastant $\times$ subject $[F(20,30)=4.79, p<0.001]$ and concentration $\times$ subject $[F(75,13,211)=2.9, p<0.05]$. Concentration effects can be described as steadily increasing flow rates for increasing concentrations and tastant effects as different intercept values for parallel concentration-flow rate functions of different tastants.

\section{Temporal Flow Rate Response}

There was no variation for the $T-F_{\text {peak }}$ between the different tastants and the concentration tested. The average time to reach the peak was usually 10 to $20 \mathrm{~s}$ after stimulation (Fig. 3). T-F $F_{\text {tot }}$ was increasing with the concentration of the taste compound. The longest $T-F_{\text {tot }}$ was reached with citric acid for concentration up to $75 \mathrm{mM}$ (Fig. 3a). Stimulations with $\mathrm{NaCl}$ do not show concentration effects on $T-F_{\text {tot }}$ (Fig. 3c).

\section{Relations pH and Flow Rate}

The maximum $\mathrm{pH}$ after stimulation was significantly correlated $(r=0.9, p<0.00001)$ to the flow rate over $1 \mathrm{~min}$ (Fig. 4a) and increased linearly from 6.4 at $0.1 \mathrm{~mL} / \mathrm{min}$ to 7.2 at $0.7 \mathrm{~mL} /$ min. Considering all the tastants, the $\mathrm{pH}$ was similar for all tastants if flow rates were similar. However, there was a high variability in $\mathrm{pH}$ values at flow rates below $0.2 \mathrm{~mL} / \mathrm{min}$. ANOVA of $\mathrm{pH}$ results, with flow rate as a covariate, revealed no significant tastant effects $[F(4,168)=0.370 ; p=0.83]$.

\section{Relations Protein and Flow Rate}

Protein concentration $\left(P_{\text {conc }}\right)$, averaged over the 5-min period after the stimulation (Fig. 4b), shows a significant decrease $(R=0.45, p<0.01)$ with flow rate $\left(F_{60} \mathrm{~s}\right)$. ANOVA of $P_{\text {conc }}$ results, with $F_{60} \mathrm{~s}$ as a covariate, revealed significant tastant effects $[F(4,174)=5.39 ; p<0.001]$. Post hoc analysis of tastant effects on $P_{\text {conc }}$ data revealed that citric acid group has a higher $P_{\text {conc }}$ than a subgroup formed by $\mathrm{MgSO}_{4}$, sucrose, and $\mathrm{MSG}$ while $\mathrm{NaCl}$ group is intermediate (Fig. 5).

Similar results were found on the amount of protein $\left(P_{\text {tot }}\right)$ secreted during the $5 \mathrm{~min}$ after stimulation which increases significantly $(R=0.58, p<0.001)$ with $F_{60} \mathrm{~s}$ (Fig. 4c). ANOVA of $P_{\text {tot }}$ results, with $F_{60}$ s as a covariate, revealed significant tastant effects $[F(4,175)=4.55 ; p<$ 0.01]. Post hoc analysis of tastant effects on $P_{\text {tot }}$ data revealed that citric acid group has a higher $P_{\text {tot }}$ than a subgroup formed by $\mathrm{MgSO}_{4}$, sucrose, and MSG while $\mathrm{NaCl}$ group is intermediate (Fig. 5).

\section{Discussion}

Taste and Flow Rate

Although different tastants may have different effects on flow rate (Speirs 1971; Hodson and Linden 2006), it is 
a

Flow rate $(\mu \mathrm{L} / \mathrm{min})$

Flow $(\mu \mathrm{L})$

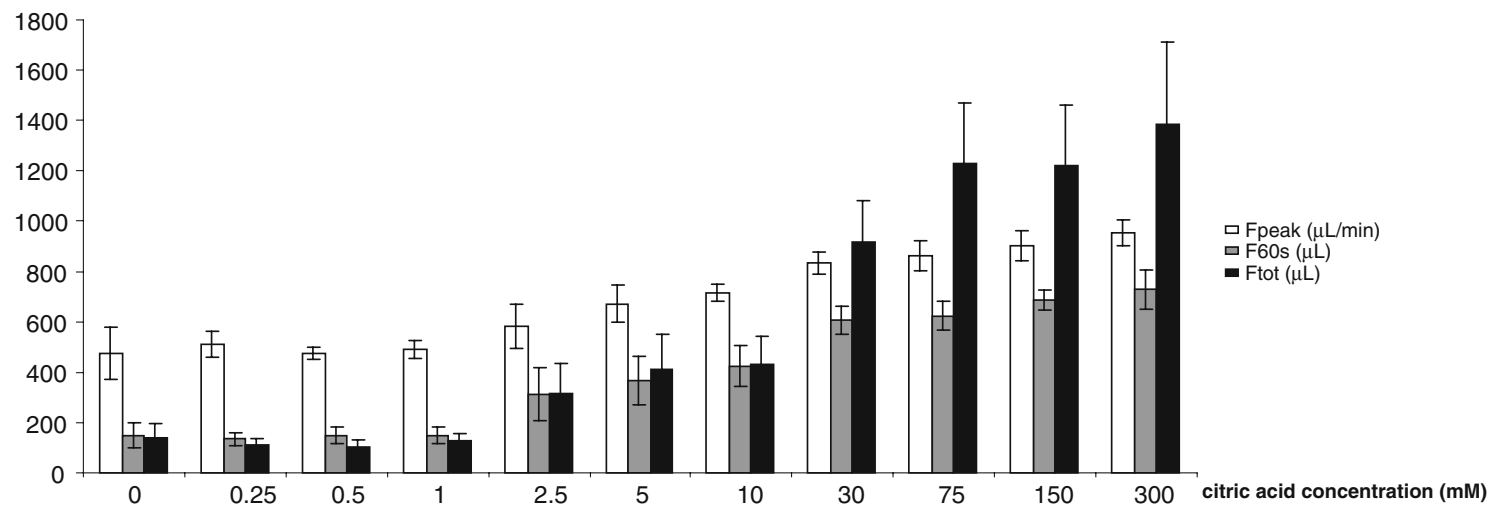

b

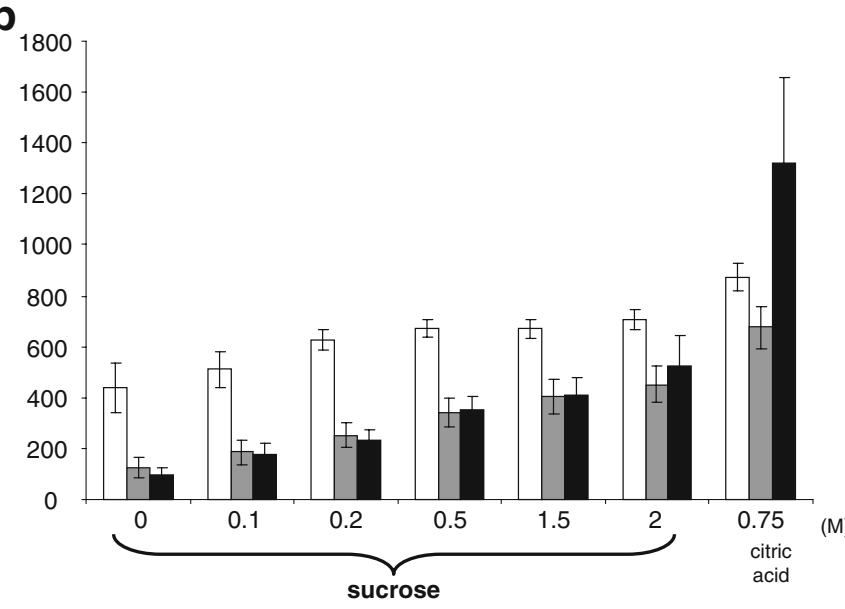

d

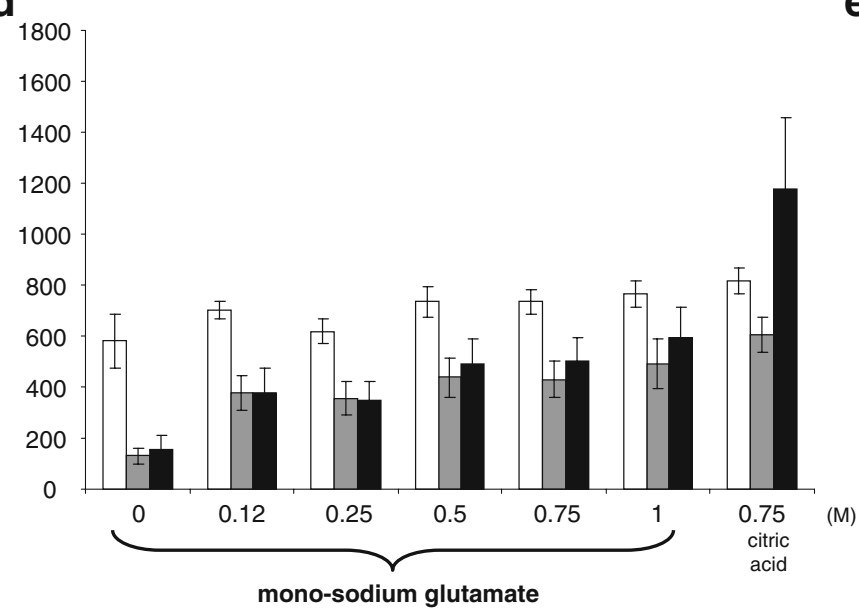

Fig. 2 Average maximum flow rate peak in white (microliters per minute), flow during $1 \mathrm{~min}$ in gray (microliters per minute) and total flow rate response in black (microliters) after stimulation by citric acid

difficult to compare them in a straightforward design since different molecules do not have the same stimulation potential at specific concentrations. One option to study whether different tastants have the same physiological effect on parotid secretions is to compare their effects when they give a similar response in terms of flow rate. Then, at
C

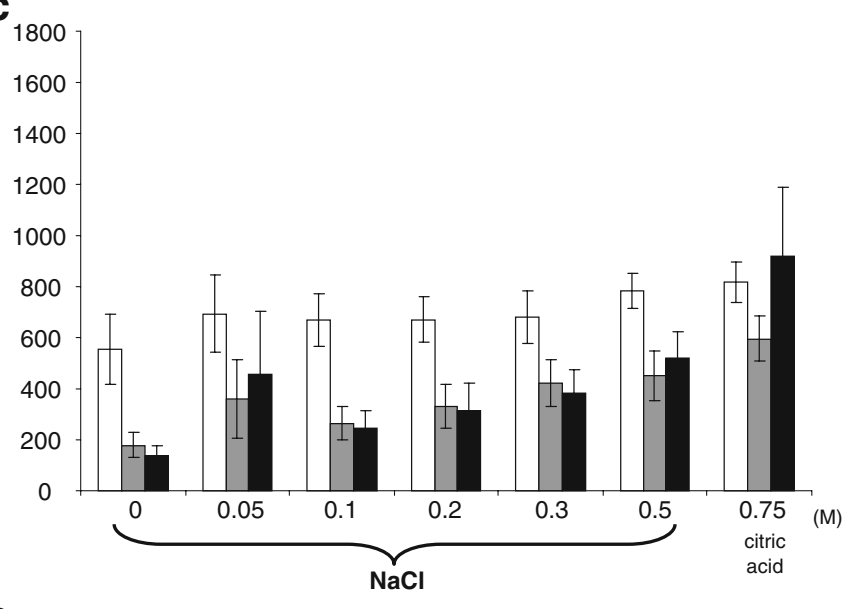

e

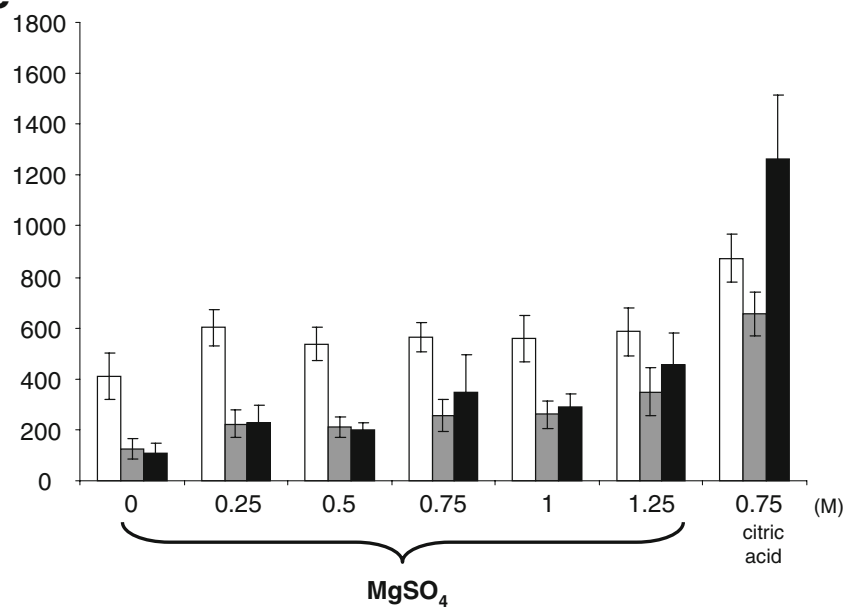

(a), sucrose (b), $\mathrm{NaCl}$ (c), monosodium glutamate (d), and $\mathrm{MgSO}_{4}(\mathbf{e})$. $N=6 \pm$ SEM

this level, it is possible to compare other characteristics like $\mathrm{pH}$ or protein concentration.

In this study, we have compared three types of measurement of flow rate: the maximum value of the peak following the stimulation $\left(F_{\text {peak }}\right)$, the flow rate during the first minute $\left(F_{60 \mathrm{~s}}\right)$, and the total response to the stimulation 
a
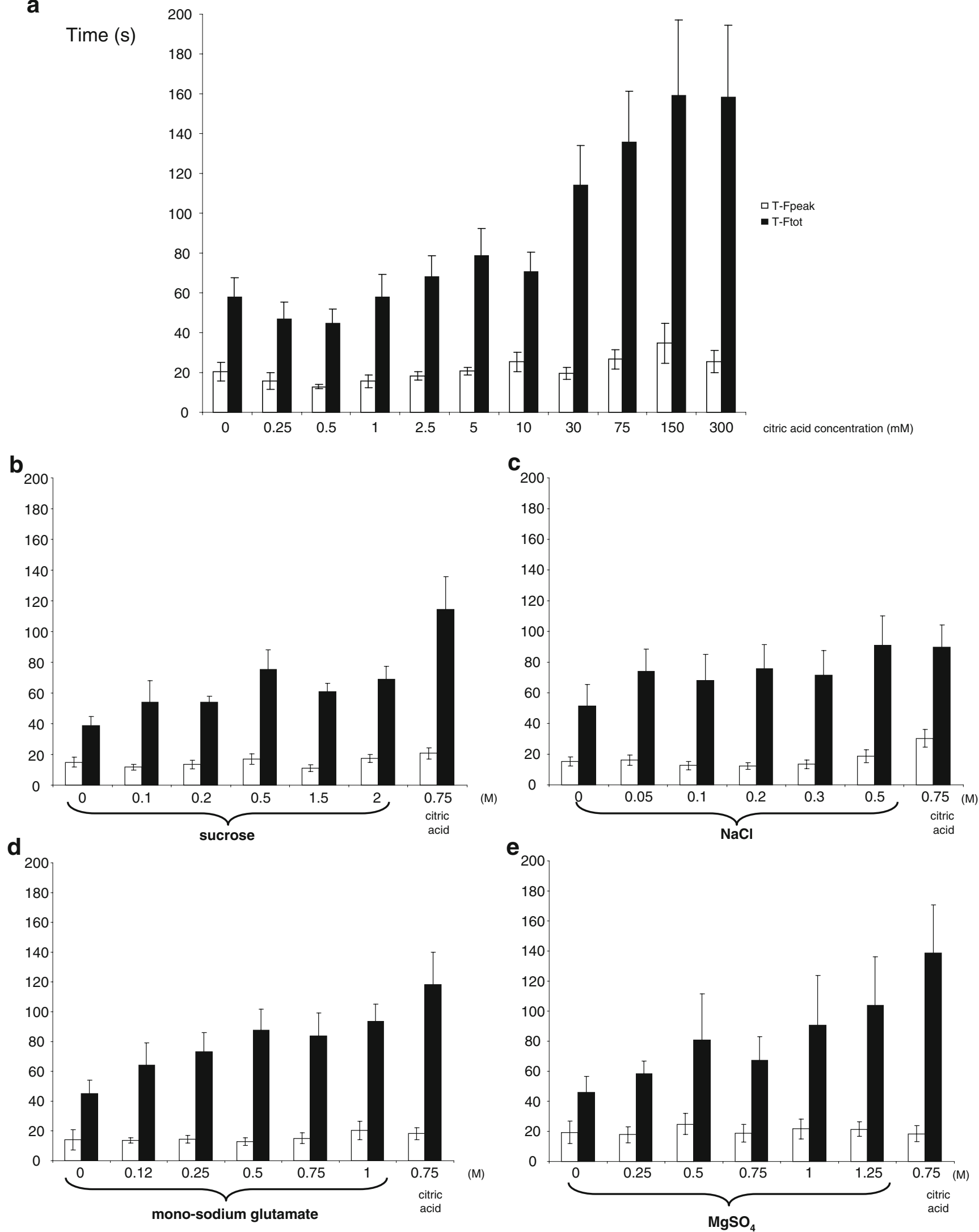

Fig. 3 Time to reach the flow rate peak (white) and total flow rate response (black) after stimulation by citric acid (a), sucrose (b), NaCl (c), monosodium glutamate (d), and $\mathrm{MgSO}_{4}$ (e). $N=6 \pm$ SEM 


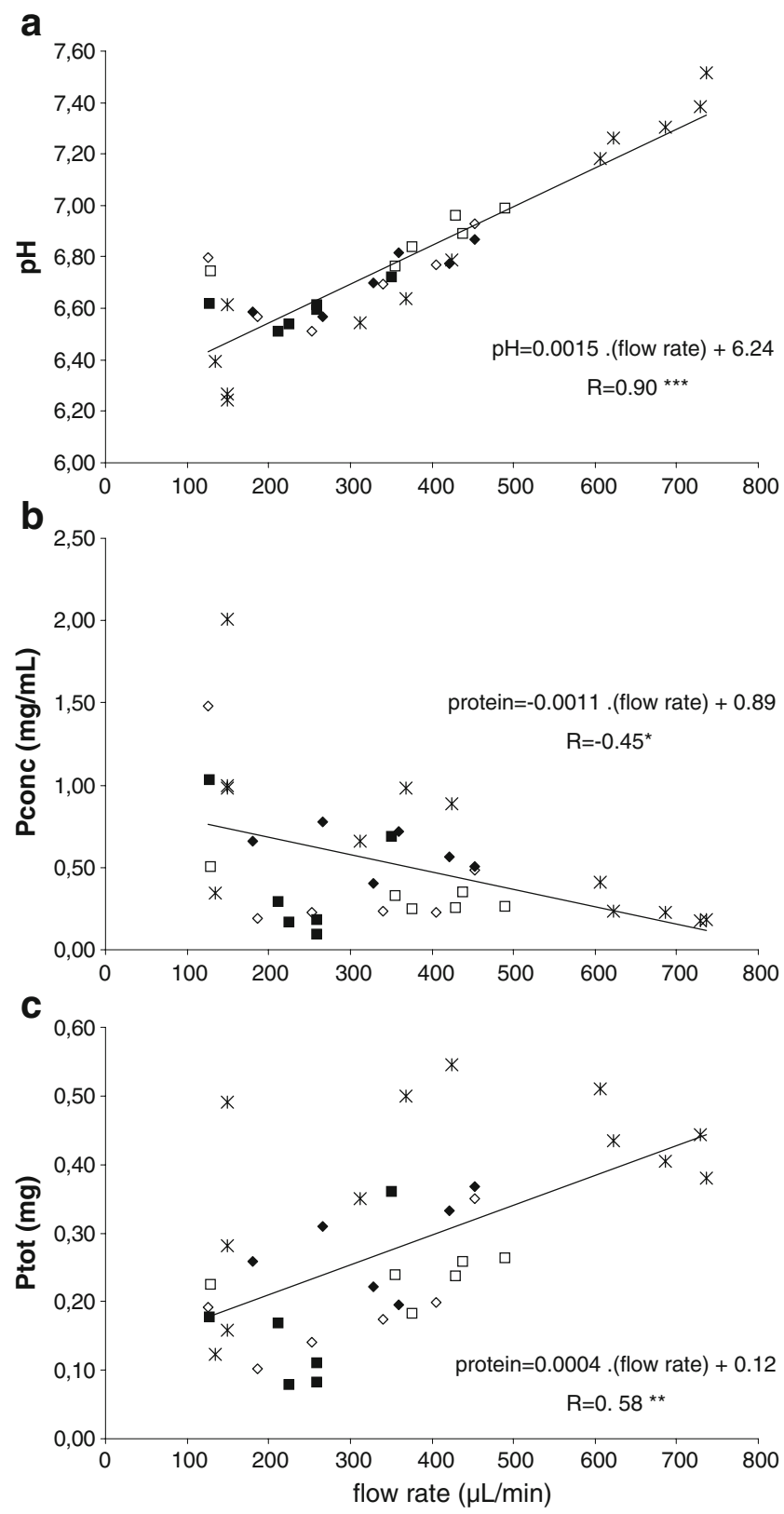

Fig. 4 Relationship between $\mathrm{pH}$ (a), protein concentration (b), total protein (c), and flow rate over the first minute after stimulation for the five different tastants. Values are the means of six subjects for citric acid (star), sucrose (open diamond), $\mathrm{NaCl}$ (closed diamond), monosodium glutamate (open square), and $\mathrm{MgSO}_{4}$ (closed square). $N=36$; ${ }^{*} p<0.01 ; * * p<0.001 ; * * * p<0.00001$

being the total flow from stimulation onset until the moment that flow returns to baseline $\left(F_{\text {tot }}\right)$. The different taste molecules were selected in order to cause complete parotid flow response in less than $1 \mathrm{~min}$.

Interestingly, time of the $F_{\text {tot }}\left(T-F_{\text {tot }}\right)$ increased with tastant concentration whereas the $F_{\text {peak }}$ did not change. This was due to a persistence of the flow rate at plateau level. The duration of this plateau was related to the concentration of the tastant which could be due to a persistence of taste stimulation. Such persistence is difficult to stop since rinsing with distilled water is not relevant, this action by itself having a stimulating effect on parotid secretions.

Tastants were chosen in line with Hodson and Linden (2006) so that results could be compared with the results from this study. At a comparable concentration of about $75 \mathrm{mM}$ citric acid, these authors observed peak values of $4 \mathrm{~mL} / \mathrm{min}$ and a first-minute flow rate of $2.5 \mathrm{~mL} / \mathrm{min}$ against 0.9 and $0.6 \mathrm{~mL} / \mathrm{min}$, respectively, in our study. These higher values can be probably due to an application of the stimulus for $30 \mathrm{~s}$, in contrast with the $10-\mathrm{s}$ presentations in the present study. Similar to this study, Hodson and Linden (2006) observed saturation plateaus from concentrations of $75 \mathrm{mM}$ and up. Similar results were found at a concentration of $30 \mathrm{mM}$ after the first minute of stimulation (Jensen-Kjeilen et al. 1987). Results concerning the other taste compounds are comparable to the ones obtained by Hodson and Linden (2006).

Taste and $\mathrm{pH}$

Linking flow rate measurements to saliva $\mathrm{pH}$ at the exit of the parotid duct cannot be achieved by classical in vitro studies in human. When collected, the delay due to the length between the collecting tubing and the Lashley cup makes impossible to recombine a physical measurement (flow rate) to a chemical measurement $(\mathrm{pH})$. Moreover, $\mathrm{pH}$ should be measured without contact with air to avoid loss of $\mathrm{CO}_{2}$ from bicarbonate ions present in saliva (Bardow et al. 2000). In this study, it is the first time that we can link flow rate with $\mathrm{pH}$ measurements without loss of $\mathrm{CO}_{2}$ after stimulation by tastants as if these were measured at the exit of the duct at high time resolution $(3.125 \mathrm{~Hz})$.

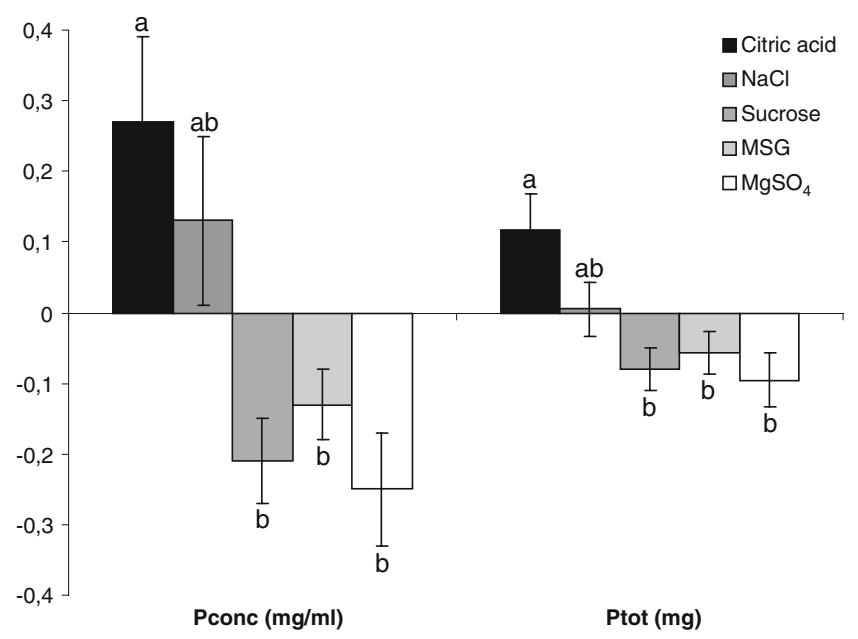

Fig. 5 Effect of tastant on protein concentration $\left(P_{\text {conc }}\right)$ and total protein $\left(P_{\text {tot }}\right)$ with flow rate as a covariate. Vertical bars show the standard error of the mean. Means lacking common letters differ significantly $\left(p<0.001\right.$ for $P_{\text {conc }}$ and $p<0.01$ for $\left.P_{\text {tot }}\right)$ 
It is known that a negative relation exists between flow rate and $\mathrm{pH}$. In parotid glands, when stimulated, $\mathrm{HCO}_{3}{ }^{-}$ ions are generally assumed to be the main responsible molecules for buffer capacity (Tabak 2006). According to the two stages model, primary fluid secreted by salivary acinar cells is a plasma-like isotonic fluid rich in bicarbonate and $\mathrm{NaCl}$ (Melvin et al. 2005). When excreted, this solution is modified during passage through the duct system. Duct cells reabsorb $\mathrm{Na}^{+}$and $\mathrm{Cl}^{-}$, secrete $\mathrm{K}^{+}$, and either absorb or secrete $\mathrm{HCO}_{3}{ }^{-}$(Roussa 2001). These phenomena invoke a decrease of $\mathrm{HCO}_{3}{ }^{-}$concentration at the exit of the duct system at lower secretory rates when the system is more efficient (Park et al. 2002). Although these molecular mechanisms are well understood, it remains still difficult to predict $\mathrm{pH}$ of parotid saliva as a function of flow rate. In this work, we have found a linear relation between $\mathrm{pH}\left(\mathrm{pH}_{\max }\right)$ after a stimulation and flow rate $\left(\begin{array}{ll}F_{60} & \mathrm{~s}\end{array}\right)$ independently of tastant nature. In 1969, Dawes (1969) found, for constant flow of parotid saliva after stimulation with sour lemon, $\mathrm{pH}$ measures decreasing from 6.8 to 7.4 for flow rates from 0.25 to $1 \mathrm{~mL} / \mathrm{min}$, respectively. Although these results are in the range we found, the author did not establish a relationship between flow rate and $\mathrm{pH}$. No important effects of the taste nature were found by the same author on the ionic composition of parotid saliva (Dawes 1984). Unfortunately, no indications about the flow rate of saliva during sample collections are available. Recently, we have found a similar relation between $\mathrm{pH}$ and flow rate after stimulation by chewing: $\mathrm{pH}=0.0025$ flow rate $(\mu \mathrm{L} / \mathrm{min})+5.74$ (Neyraud et al. 2009). This gives support to the fact that the relation between $\mathrm{pH}$ of parotid saliva does not depend of the nature of the stimulus but of the flow rate induced by this one.

\section{Taste and Proteins}

In this report, we did observe a decrease of protein concentration $\left(P_{\text {conc }}\right)$ with increasing flow rate $\left(\begin{array}{lll}F_{60} & \mathrm{~s}\end{array}\right)$. Interestingly, this protein decrease is spurious and only due to dilution since the total amount of protein $\left(P_{\text {tot }}\right)$ released per time unit actually increases with flow rate. Although significant, these relationships are not clear since values given after stimulation by citric acid at high flow are influencing strongly the relationships and $F_{60}$ s larger than $500 \mu \mathrm{L}$ were not achieved by other tastants.

Mechanisms for secretion of proteins in parotid glands are discussed in full detail in review articles (Turner and Sugiya 2002; Gorr et al. 2005) that generally support the notion that secretion is controlled by the autonomic nervous system. The sympathetic nervous system tends to evoke greater release of proteins and even higher when in synergy with the parasympathetic system (Proctor and Carpenter 2007). Some authors suggested that release of proteins in parotid saliva may depend on the nature of the stimulus. When compared to other tastants, citric acid stimulation results in a lower concentration in protein with a higher $\alpha$ amylase activity (Froehlich et al. 1987). Unfortunately, the comparison was done for constant taste perception levels and not for constant flow rates. At a constant flow rate, Dawes (1984) had reported a higher protein concentration after stimulation by $\mathrm{NaCl}$. Without flow rate effects, we did observe a higher amount of protein after citric acid stimulation compared to sucrose, $\mathrm{MSG}$, and $\mathrm{MgSO}_{4}$ while $\mathrm{NaCl}$ evokes intermediate protein release. Increase of protein amount has already been reported by Dawes at a constant flow rate after long stimulation by $\mathrm{NaCl}$. Also, an increase of $\alpha$-amylase activity has been reported by Speirs et al. (1974) after application of ascorbic acid on the tongue and with stimulation of the sympathetic system. The authors suggested that such an oversecretion of protein could be due, in some way, to an increase of the ratio of sympathetic to parasympathetic stimulation of the gland causing a higher rate of protein secretion (Dawes 1984). A possible additive explanation could be the activation of the trigeminal lingual system in addition to the taste sensation after stimulation by acids conducting in sensations of irritation. Indeed, it has been reported that during perception of acid, the trigeminal free nerve ending are also stimulated (Lugaz et al. 2005). Recently, an overexpression of protein secretion in whole saliva has been found after stimulation by tastants with the strongest modification of the whole saliva proteome after stimulation by acid (Neyraud et al. 2006). The apparent oversecretion of protein in parotid saliva after stimulation by acid can be due to a synergic participation of the gustatory and trigeminal system.

\section{Conclusion}

This is the first time that flow rate, $\mathrm{pH}$, and protein concentration and amount of saliva from parotid glands can be calculated as it were assessed at the exit of the parotid duct after stimulation by tastants. The linear relationship between flow rate and $\mathrm{pH}$ was established allowing the calculation of $\mathrm{pH}$ from flow rate. For protein concentration and total protein amount after stimulation, this relation is not clear. However, after correcting for flow rate effects, protein concentration and protein amount are significantly higher for stimulation by citric acid than for stimulation by sucrose, $\mathrm{MgSO}_{4}$, and MSG.

Acknowledgments We wish to thank Celine Brattinga and Natasja Huck for their help during saliva collection, Dr Markus Stieger for his valuable comments on this manuscript, and the European Commission (DiOGenes, http://www.diogenes-eu.org/, contract no. FP6-FOODCT-2005-513946) for the financial support. 
Open Access This article is distributed under the terms of the Creative Commons Attribution Noncommercial License which permits any noncommercial use, distribution, and reproduction in any medium, provided the original author(s) and source are credited.

\section{References}

Bardow A, Moe D, Nyvad B, Nauntofte B (2000) The buffer capacity and buffer systems of human whole saliva measured without loss of $\mathrm{CO}_{2}$. Arch Oral Biol 45:1-12

Chauncey HH, Shannon IL (1960) Parotid gland secretion rate as method for measuring response to gustatory stimuli in humans. Proc Soc Exp Biol Med 103:459-463

Christensen CM, Brand JG, Malamud D (1987) Salivary changes in solution $\mathrm{pH}$ : a source of individual differences in sour taste perception. Physiol Behav 40:221-227

Dawes C (1969) The effects of flow rate and duration of stimulation on the concentrations of protein and the main electrolytes in human parotid saliva. Arch Oral Biol 14:277-294

Dawes C (1984) Stimulus effects on protein and electrolyte concentrations in parotid saliva. J Physiol 346:579-588

Froehlich DA, Pangborn RM, Whitaker JR (1987) The effect of oral stimulation on human parotid salivary flow rate and alphaamylase secretion. Physiol Behav 41:209-217

Gorr SU, Venkatesh SG, Darling DS (2005) Parotid secretory granules: crossroads of secretory pathways and protein storage. J Dent Res 84(6):500-509

Harthoorn L, Brattinga C, van Kekem K, Neyraud E, Dransfield E (2008) Effects of sucrose on salivary flow and composition: differences between real and sham intake. Int J Food Sci Nutr 16:1-10

Hodson NA, Linden RWA (2006) The effect of monosodium glutamate on parotid salivary flow in comparison to the response to representatives of the other four basic tastes. Physiol Behav 89:711-717

Humphrey SP, Williamson RT (2001) A review of saliva: normal composition, flow, and function. J Prosthet Dent 85:162-169
Jensen-Kjeilen JC, Brodin P, Aars H, Berg T (1987) Parotid salivary flow in response to mechanical and gustatory stimulation in man. Acta Physiol Scand 131:169-175

Lugaz O, Pillias AM, Boireau-Ducept N, Faurion A (2005) Timeintensity evaluation of acid taste in subjects with saliva high flow and low flow rates for acids of various chemical properties. Chem Senses 30:89-103

Melvin JE, Yule D, Shuttleworth T, Begenisich T (2005) Regulation of fluid and electrolyte secretion in salivary gland acinar cells. Annu Rev Physiol 67:445-469

Mese H, Matsuo R (2007) Salivary secretion, taste and hyposalivation. J Oral Rehabil 34:711-723

Neyraud E, Sayd T, Morzel M, Dransfield E (2006) Proteomic analysis of human whole and parotid salivas following stimulation by different tastes. J Proteome Res 5:2474-2480

Neyraud E, Bult JHF, Dransfield E (2009) Continuous analysis of parotid saliva during resting and short-duration simulated chewing. Arch Oral Biol. doi: 10.1016/j.archoralbio.2009.01.005

Park K, Hurley PT, Roussa E, Cooper GL, Smith CP, Thévenod F, Steward MC, Case RM (2002) Expression of a sodium bicarbonate cotransporter in human parotid salivary glands. Arch Oral Biol 47:1-9

Proctor GB, Carpenter GH (2007) Regulation of salivary gland function by autonomic nerves. Auton Neurosci Basic 133:3-18

Roussa $\mathrm{E}(2001) \mathrm{H}^{+}$and $\mathrm{HCO}_{3}{ }^{-}$transporters in human salivary ducts. An immunohistochemical study. Histochem J 33:337-344

Speirs RL (1971) The effects of interactions between gustatory stimuli on the reflex flow-rate of human parotid saliva. Arch Oral Biol $16: 351-365$

Speirs RL, Herring J, Cooper WD, Hardy CC, Hind CRK (1974) The influence of sympathetic activity and isoprenaline on the secretion of amylase from the human parotid gland. Arch Oral Biol 19:747-752

Tabak LA (2006) In defense of the oral cavity: the protective role of the salivary secretions. Pediatr Dent 28(2):110-117

Turner RJ, Sugiya H (2002) Understanding salivary fluid and protein secretion. Oral Dis 8:3-11 